\title{
EFEKTIFITAS PENERAPAN HYPNOBIRTHING DALAM MENURUNKAN TINGKAT KECEMASAN IBU HAMIL TRIMESTER TIGA MENJELANG PERSALINAN ANAK PERTAMA DI USIA DEWASA AWAL
}

\author{
Kamilia Asmarany \\ Psikologi, Fakultas Ilmu Pendidikan, Universitas Negeri Jakarta \\ Jl. Halimun No., Jakarta \\ E-mail: asmaranykamilia@gmail.com
}

\begin{abstract}
The aim of this study is to find the influence of hypnobirthing method to decrease level's of anxiety of early adult women's confinement . The research was held in Ningsih Midwife's from March until June 2012. This research used experimental research method which is kind of quasi experiment with one-group pre-posttest design. Analysis obtainded using the Wilcoxon test $\mathrm{z}=$ $3.061, p=0.002<0.05$ (significant), meaning that there are significant differences in before and after hypnobirthing. From these results it was found that there are significant difference between groups of measurements before. Based on the results of this analysis, the hypothesis of this study is acceptable. This research's hypothesis is hypnobirthing method effective to reduce anxiety in the first child labour in early adult mother. The implication of this research is hypnobirthing method can decrease the pregnant women's level of anxiety towards confinement and easy to be executed. This method can be applied not only at midwife but also in pregnant women by her self..
\end{abstract}

Keywords: anxiety, hypnobirthing method, early adult mother

\section{Pendahuluan}

Kehamilan adalah suatu keajaiban sekaligus amanat dari Allah SWT. Hendaknya setiap wanita merasa bersyukur atas kehamilan tersebut karena tidak semua wanita dapat merasakan kehadiran seorang janin di dalam rahimnya. Selama sembilan bulan wanita akan merasakan kehidupan bayi di dalam rahimnya dan harus menjaganya serta saling berbagi dalam berbagai hal karena sesungguhnya rahim (berasal dari bahasa Arab) berarti kasih dan sayang. Kelembutan, kasih, dan sayang sangat dibutuhkan selama proses kehamilan sehingga anak lahir dengan penuh kebaikan.
Bagi beberapa wanita, kehamilan merupakan hal yang dapat membawa kebahagian sekaligus sebuah kecemasan. Dikatakan membawa kebahagiaan karena kehamilan merupakan suatu peristiwa dan pengalaman yang sangat penting dalam hidup seorang wanita dimana ia telah merasa menjadi seorang wanita secara utuh. Dikatakan kecemasan karena merasa cemas apa yang akan terjadi pada diri dan bayinya saat proses persalinan. Pada umumnya, kehamilan pertama memiliki lebih banyak masalah psikologis dibandingkan ibu yang hamil anak kedua dan setelahnya. Wanita yang hamil untuk pertama kali dibandingkan dengan wanita yang telah hamil sebelumnya menunjukan kecemasan yang lebih pada diri dan bayinya serta timbulnya perasaan mudah tersinggung dan merasa tegang (Erickson dalam Williams, 1996). 
Ibu hamil pertama tidak jarang memiliki pikiran yang mengganggu karena adanya reaksi kecemasan terhadap cerita yang diperolehnya tentang proses persalinan. Hampir semua orang selalu mengatakan bahwa melahirkan itu sakit sekali. Oleh karena itu, muncul rasa cemas pada ibu hamil pertama yang belum memiliki pengalaman bersalin.

Pandangan lain mengatakan bahwa pada usia kandungan tujuh bulan ke atas, tingkat kecemasan ibu hamil semakin menjadi dan intensif seiring dengan mendekatnya kelahiran bayi pertamanya. Di samping itu, trimester ini merupakan masa riskan terjadinya kelahiran bayi prematur sehingga menyebabkan tingginya kecemasan pada ibu hamil. Secara hormonal, kecemasan dapat disebabkan karena adanya penurunan hormon endorfin. Hormon endorfin adalah hormon yang secara alami diproduksi oleh tubuh dan berfungsi sebagai analgesik alami. Menurut penelitian dalam Batbual (2010), endorfin memikili kekuatan 200 kali lipat dari pada morfin. Peningkatkan produksi endorfin dapat diperoleh dengan menciptakan kondisi tenang pada tubuh

Selama kehamilan, wanita merasakan perubahan-perubahan baik secara fisik dan psikis yang terjadi akibat dari perubahan hormon. Perubahan fisik terlihat jelas dengan meningkatnya bobot tubuh dan beberapa sistem kerja organ tubuh serta hormon yang dihasilkan tubuh sedangkan perubahan psikis adalah efek dari perubahan hormonal sehingga mempengaruhi emosi seperti lebih sensitif. Selama hamil, wanita juga membutuhkan dukungan emosional dari pasangan serta orang-orang terdekat untuk beradaptasi terhadap kehamilan dan menyiapkan dirinya untuk berperan menjadi seorang ibu.

Pada beberapa wanita, kegelisahan dan ketidaknyamanan fisik pada minggumingu terakhir masa kehamilan ditampilkan dengan meningkatknya aktifitas hingga hampir tidak pernah tinggal diam. Hal ini dirangsang dari dorongan-dorongan untuk "melupakan" keresahan hatinya. Akibatnya adalah memperlambat kelahiran bayinya, perpanjangan dari masa kehamilan, dan kelahiran bayi menjadi tertunda disebabkan masalah psikis berupa kegelisahan hati dan keinginan mau cepat-cepat melahirkan (Kartono, 1992). Dalam sebuah penelitian oleh Jatmika (1999) menunjukan bahwa lama persalinan kala I memiliki hubungan yang signifikan dengan tingkat kecemasan saat proses persalinan. Semakin tinggi tingkat kecemasan maka semakin lama persalinan kala I.

Rasa takut akan menghalangi proses persalinan karena ketika tubuh manusia mendapatkan sinyal rasa takut, tubuh akan mengaktifkan pusat siaga dan pertahanan. Perubahan psikologis pada masa kehamilan yang tidak dapat ditangani oleh calon ibu umumnya akan menyebabkan terjadinya kecemasan pada calon ibu. Dilihat dari segi psikologis, persalinan merupakan suatu kejadian penuh dengan stres yang menyebabkan peningkatan rasa nyeri, takut dan cemas. Menurut Batbual (2010), dalam ilmu kedokteran, rasa nyeri merupakan suatu hubungan kompleks antara berbagai macam faktor fisik dan psikis.

Menurut Dr. Tb Erwin Kusuma, SpKj (dalam Aprilia, 2011), rasa cemas pada banyak orang dewasa sekarang adalah akibat dari rekaman getaran mereka sejak dalam kandungan. Pada kenyataannya bayi dalam kandungan perlu mendapatkan ketenangan dan kedamaian dari ibunya. Kecemasan dan stress yang berlebihan pada saat hamil sama dengan ibu hamil perokok. Keadaan tersebut bisa mengakibatkan bayi lahir prematur, kesulitan belajar, anak menjadi hiperaktif atau bahkan mengalami autisme, sedangkan bagi ibu akan mengakibatkan kadar hormon prognanolone dalam tubuh tidak mencukupi.

Ibu hamil yang sering kali merasa khawatir bahkan stres memiliki kecenderungan untuk melahirkan bayi prematur. Selain itu, efek dari rasa cemas tersebut dapat membuat bayi saat lahir memiliki berat badan tubuh $<2500$ gram yang termasuk sangat kurang untuk ukuran seorang bayi (Hamilton, et al., dalam Batbual, 2010). Dalam sebuah penelitian lain menunjukan bahwa terdapat hubungan antara emosi ibu dengan apa yang janin rasakan. Sejak janin berusia enam bulan, ia sudah bisa merasakan emosi ibunya melalui hormon ibu yang disalurkan pada janin (Andriana, 2007). Akibatnya, proses 
persalinan dengan pembedahan lebih banyak dipilih oleh ibu hamil sebagai cara persalinan.

Berikut adalah beberapa cerita atau pengalaman dari ibu yang mengalami kecemasan menjelang persalinan berdasarkan hasil wawancara:

"Saya lebih memilih proses operasi karena dari pengalaman dan cerita yang saya dengar percuma aja udah sampe pembukaan delapan dan sakit-sakit tapi akhirnya harus tetap di operasi juga." Fairus-

"Saya takut buta karena sehabis melahirkan mata teman saya menjadi sangat merah dan bengkak. Waktu saya tanya kenapa, katanya saat dia mengejan dia sempat memejamkan mata sehingga pembuluh mata nya putus. " -Lilis Setiawaty-

"Saya dengar cerita dari keluarga saya yang udah pernah melahirkan sakitnya pas dijahit sangat menyiksa selain itu bisa bikin vagina menjadi lebar. Saya gak mau bikin kecewa suami saya."-Ria-

Dari pernyataan di atas, terlihat bahwa untuk beberapa wanita melahirkan secara alami atau normal adalah hal yang menakutkan sehingga dapat menimbulkan kecemasan. Efek dari rasa cemas dan stres saat ibu hamil tersebut akan mempengaruhi jiwa ibu dan bayi dalam kandungannya. Secara psikologis, ibu yang tidak tenang dapat menurunkan kondisi tersebut kepada bayi sehingga bayi akan menjadi mudah merasa gelisah dan berdampak pada kesehatannya. Hal ini terjadi karena apa yang tertanam dalam pikiran ibu akan tertanam pula pada bayi lewat hubungan batin yang kuat antara ibu dan bayi. Akibatnya, proses persalinan secara alami atau normal pun semakin kurang diminati oeh ibu hamil karena pikiran akan rasa sakit dan nyeri saat proses persalinan. Oleh karena itu, dibutuhkan cara untuk mengatasi rasa nyeri saat proses persalinan.

Saat ini, terdapat berbagai macam cara mengatasi rasa nyeri untuk proses persalinan baik secara farmakologis atau menggunakan obat maupun nonfarmakologis atau tanpa obat-obatan.
Cara-cara farmakologis adalah penggunaan obat-obatan seperti penggunaan analgesia yaitu berupa cairan yang dimasukan ke dalam tubuh sehingga tidak merasakan nyeri atau kontraksi. Pada kenyataannya, penggunaan analgesia memiliki dampak negatif seperti depresi, gangguan pernapasan ibu maupun janin, mual, muntah hingga ketergantungan (Twycross, 1994, dalam Batbual, 2010). Adapun cara non-farmakologis yaitu dengan cara mengurangi hingga menghilangkan nyeri tanpa penggunaan obat-obatan sehingga efek negatif dapat dihindari. Cara non-farmakologis yang sering digunakan saat ini seperti terapi manual dengan sentuhan, terapi musik, air, relaksasi, dan hypnobirthing.

Pada tahun 1914, Dr. Grantly Dick-Read, seorang dokter Inggris mengemukakan bahwa rasa sakit pada proses bersalin timbul dari rasa takut. Untuk menghilangkan rasa takut tersebut, ia menyarankan persalinan alami (natural childbirth); mendidik para wanita dengan psikologi reproduksi dan melatih mereka dengan latihan fisik, pernapasan, dan relaksasi pada saat persalinan dan kelahiran (Papalia, Old, dan Feldman, 2008).

Seperti yang telah dijelaskan diatas bahwa untuk mengurangi kecemasan saat ini terdapat beberapa metode dan salah satunya adalah metode yang menggunakan hipnosis. Penggunaan hipnosis dalam menangani kecemasan menghadapi persalinan merupakan metode yang sangat terkenal di Amerika Serikat, dan telah menjadi bidang kajian tersendiri yang telah teruji keilmiahannya. Konsep hipnotis yang khusus di berlakukan pada ibu hamil, popular dengan sebutan hypnostetri atau hypnobirthing. Hypnobirthing merupakan metode untuk mencapai relaksasi mendalam, menggunakan pola pernapasan lambat, fokus, tenang dan dalam keadaan sadar sepenuhnya.

Di Indonesia, hypnobirthing belum cukup banyak diketahui oleh orangorang karena kurangnya sosialisasi terutama ke rumah sakit dan rumah bersalin. Lanny Kuswandi, seorang bidan dan Dr. Tb Erwin Kusuma, SpKj, merupakan orang yang mengembangkan metode hypnobirthing di Indonesia. Dalam mengembangkan metode 
hypnobirthing, diadakan pelatihanpelatihan untuk bidan maupun perawat untuk mempelajari metode hypnobirthing akan tetapi biaya untuk mengikuti pelatihan hypnobirthing yang cukup mahal mengakibatkan tidak semua dapat mengikuti pelatihan tersebut.

$$
\text { Hypnobirthing memiliki }
$$
keunggulan dibandingkan metodemetode lain karena tidak membutuhkan peralatan yang sulit dan biaya yang terjangkau. Selain itu, hypnobirthing banyak memberikan manfaat karena melatih ibu hamil untuk selalu rileks, bersikap tenang dan menstabilkan emosi. Hypnobirthing bertujuan agar ibu merasa tenang sejak masa kehamilan sehingga dapat melahirkan dengan nyaman dan menghilangkan rasa sakit melahirkan tanpa bantuan obat bius apapun dan tidak ketergantungan terhadap obat kimia. Metode ini juga lebih menekankan melahirkan dengan cara menanamkan pikiran positif, lembut, aman dan bagaimana menjalani proses persalinan dengan mudah.

Keunggulan lain yang dimiliki metode hypnobirthing adalah ibu hamil akan dilatih untuk menanamkan pikiran positif dan melakukan hipnosis diri atau self-hypnosis sehingga tidak membutuhkan pendamping setelah diberikan beberapa bimbingan di awal. Relaksasi yang mendalam, pemusatan perhatian (fokus), dan hipnosis berguna untuk lebih banyak memasukkan pemahaman kepada alam bawah sadar sehingga tindakan akan lebih banyak dipengaruhi oleh alam bawah sadar dibandingkan dengan alam sadar.

Beberapa penelitian membuktikan bahwa metode hipnosis dapat meminimalkan dan bahkan menghilangkan rasa takut, ketegangan, sindrom rasa sakit dan kepanikan selama proses persalinan serta periode setelahnya sehingga tidak menjadi truma pasca persalinan dibandingkan dengan metode lain seperti aromaterapi, akupuntur, audio-analgesia, dan pijatan (Smith et, al, 2006). Penelitian lain yang dilakukan oleh Cyna et,al (2006) membuktikan bahwa metode hipnosis metode sederhana efektif untuk mengurangi penanganan dengan obatobatan kimia saat persalinan dan menghemat pengeluaran dalam perawatan saat persalinan dan setelahnya. Penelitian yang dilakukan oleh mahasiswa kedokteran di Surakarta menunjukan bahwa metode hypnobirthing memiliki pengaruh yang positif dan signifikan dalam mengurangi tingkat kecemasan dan lama proses persalinan.

Berdasarkan teori-teori tersebut maka hipotesis yang diajukan dalam penelitian ini adalah penerapan metode hypnobirthing efektif dalam menurunkan tingkat kecemasan menjelang persalinan anak pertama pada ibu usia dewasa awal.

\section{Metode Penelitian}

Tipe penelitian ini adalah eksperimen yaitu jenis kuasi eksperimen karena dalam penelitian ini tidak ada kelompok kontrol dan desainnya adalah One Group Pretest-Postest Design. Variabel tergantung dalam penelitian ini adalah kecemasan menjelang persalinan anak pertama, yaitu respon yang muncul pada ibu hamil trimester tiga menjelang persalinan pertama yang penyebabnya tidak diketahui. Variabel bebas adalah hypnobirthing yang merupakan sebuah metode baru yang menggunakan self hypnosis dan bertujuan untuk membuat ibu hamil menikmati kehamilannya hingga masa persalinan dengan nyaman, aman, dan tenang.

Subjek penelitian ini adalah ibu hamil usia trimester tiga yang akan menghadapi persalina anak pertama. Jumlah subjek dalam penelitian ini sebanyak 12 orang. Teknik yang digunakan dalam mengambil subjek adalah dengan purposive sampling, yaitu karakteristik subjek telah ditentukan sesuai tujuan penelitian. Adapun karakteristi-karakteristiknya adalah: (1) usia kehamilan $>7$ bulan (28 minggu); (2) kehamilan anak pertama; (3) pendidikan minimal SMA/SMK; (4) berusia 20-30 tahun; (5) kondisi kehamilan sehat tanpa kelainan medis; (6) mengalami kecemasan berdasarkan hasil wawancara pendahuluan.

Sebelum memberikan perlakuan, peneliti terlebih dahulu melakukan wawancara pendahuluan untuk survei terhadap 40 orang ibu hamil untuk memperoleh gambaran tentang kecemasan yang dirasakan ibu hamil terutama yang berkaitan dengan proses 
persalinan anak pertama yang akan dihadapi. Setelah mendapatkan hasil tersebut, peneliti menentukan subjek yang akan dipilih untuk mengikuti penelitian ini. Skala kecemasan menjelang persalinan anak pertama berdasarkan teori gejala kecemasan dari Maramis (1980) yang membedakan gejala kecemasan menjadi empat komponen yaitu komponen psikologis, komponen somatik, komponen koginitif, dan komponen motorik. Skala terdiri dari empat pilihan jawaban yang diberikan sebelum diberikan perlakuan (pretest) dan diberikan kembali setelah subjek mendapatkan perlakuan hypnobirthing (posttest). Selain itu, digunakan kuesioner data diri untuk memperoleh identitas diri subjek penelitian dan beberapa data dari kuesioner digunakan sebagai data variabel yang akan dikontrol. Pelaksanaan hypnobirthing diberikan oleh tenaga profesional yang sudah sering memberikan kelas hypnobirthing.

Analisis statistik yang digunakan adalah analisis statistik uji dua sampel yang berhubungan yaitu analisis perbedaan skor kecemasan sebelum mendapat perlakuan dan setelah mendapat perlakuan, yaitu dengan $\mathrm{Uji}_{\mathrm{j}}$ Wilcoxon.

\section{Hasil \& Diskusi}

Hasil analisis statistik dengan uji Wilcoxon menunjukan adanya perbedaan kecemasan menjelang persalinan anak pertama sebelum diberikan hypnobirthing dan setelah diberikan perlakuan hypnobirthing.

Tabel 1 Hasil analisis uji Wilcoxon

\begin{tabular}{lcc}
\hline & Nilai Z & Signifikansi \\
\hline Sesudah & -3.061 & 0.002 \\
Sebelum & & \\
\hline
\end{tabular}

Berikut adalah perubahan tingkat kecemasan ibu hamil trimester tiga menjelang persalinan anak pertama sebelum mendapatkan perlakuan hypnobirthing (pretest) dan setelah mendapatkan perlakuan hypnobirthing (posttest).

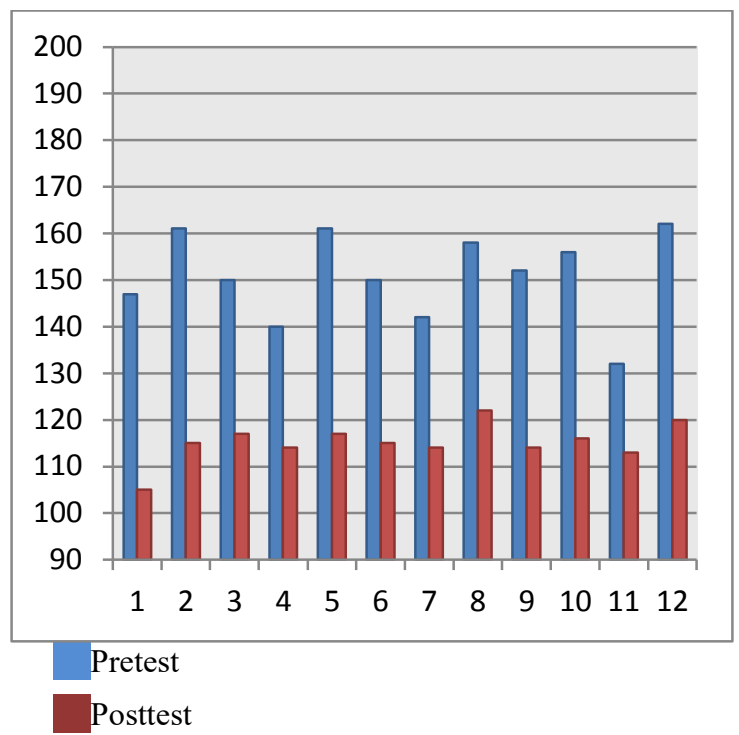

Gambar 1 Skor Pretest dan Posttest Kecemasan Menjelang Persalinan Anak Pertama

Hipotesis yang berbunyi penerapan metode hypnobirthing efektif dalam menurunkan tingkat kecemasan menjelang persalinan anak pertama pada ibu usia dewasa awal diterima.

Tingkat kecemasan subjek penelitian sebelum diberikan perlakuan hypnobirthing berada di kategori tinggi sebanyak empat orang dan kategori sedang delapan orang. Setelah diberikan perlakuan hypnobirthing, seluruh subjek berada di kategori sedang dengan perubahan skor kecemasan yang signifikan.

Berdasarkan hasil penelitian ini, hypnobirthing terbukti memiliki dampak positif dalam membantu mengurangi tingkat kecemasan ibu hamil menjelang persalinan anak pertama. Empat teknik dasar dalam hypnobirthing yaitu teknik relaksasi dengan pernapasan, teknik relaksasi otot, teknik visualisasi dengan relaksasi pelangi, dan berkomunikasi dengan janin memberian efek relaksasi.

Wanita yang hamil untuk pertama kali dibandingkan dengan wanita yang telah hamil sebelumnya menunjukan kecemasan yang lebih pada diri dan bayinya serta timbulnya perasaan mudah tersinggung dan merasa tegang (Erickson dalam Williams, 1996). Ibu hamil pertama tidak jarang memiliki pikiran yang mengganggu karena adanya reaksi kecemasan terhadap cerita 
yang diperolehnya tentang proses persalinan. Menurut Kartono (1992), pertanyaan dan bayangan apakah dapat melahirkan normal, cara mengejan, apakah akan terjadi sesuatu saat melahirkan, atau apakah bayi lahir selamat. Hal ini mengakibatkan reaksi fisik dan psikologis pada ibu.

Dengan metode hypnobirthing dapat membantu menanamkan keyakinan pada ibu hamil bahwa dapat mengalami persalinan secara alami dengan tenang, nyaman, dan percaya diri. Latihan ini mengajarkan ibu hamil menjalankan teknik relaksasi yang alami, sehingga tubuh dapat bekerja dengan seluruh syaraf secara harmonis. Rangkaian metode hypnobirthing mulai dari relaksasi otot, teknik pernapasan, teknik visualisasi dengan relaksasi pelangi dan berkomunikasi dengan janin yang dilakukan secara teratur dan konsentrasi akan menyebabkan kondisi rileks pada tubuh sehingga tubuh memberikan respon untuk mengeluarkan hormon endorfin yang membuat ibu menjadi rileks dan menurunkan rasa nyeri terutama ketika otak mencapai gelombang alfa atau saat relaksasi. Pada kondisi ini saat tubuh mengeluarkan hormon serotonin dan endorfin sehingga manusia dalam kondisi rileks tanpa ketegangan dan kecemasan (Kuswandi, 2011).

Hasil dari penelitian hypnobirthing menunjukan penurunan tingkat kecemasan menjelang persalinan anak pertama yang signifikan setelah mengikuti hypnobirthing. Hasil analisis data dengan menggunakan uji Wilcoxon menemukan yaitu $\mathrm{z}=-3.061 ; \mathrm{p}=$ $0.002<0.05$ (signifikan). Dari hasil tersebut didapatkan bahwa ada penurunan yang signifikan signifikan antara pengukuran sebelum perlakuan (pretest) dan sesudah perlakuan (posttest) yaitu metode hypnobirthing.

\section{Kesimpulan}

Berdasarkan hasil pengolahan data dan analisa data hasil penelitian yang dilakukan, diperoleh kesimpulan bahwa hipotesis nol (Ho) yang menyatakan bahwa tidak efektifnya penerapan metode hypnobirthing dalam menurunkan tingkat kecemasan ibu hamil trimester tiga menjelang persalinan anak pertama di usia dewasa awal ditolak sehingga hipotesis penelitian $(\mathrm{Ha})$ yang menyatakan bahwa penerapan metode hypnobirthing efektif dalam menurunkan tingkat kecemasan ibu hamil trimester tiga menjelang persalinan anak pertama di usia dewasa awal diterima. Oleh karena itu, dapat disimpulkan bahwa penerapan metode hypnobirthing efektif dalam menurunkan tingkat kecemasan ibu hamil trimester tiga menjelang persalinan anak pertama di usia dewasa awal

\section{Daftar Pustaka}

Andriana, E. (2007). Melahirkan Tanpa Rasa Sakit dengan Metode Relaksasi Hypnobirthing. Jakarta: PT Bhuana Ilmu Populer.

Aprillia, Y. (2010). Hipnostetri (Rileks, Nyaman, dan Aman Saat Hamil dan Melahirkan). Jakarta: Gagas Media.

Aprillia, Y. (2011). Siapa Bilang Melahirkan itu Sakit. Yogyakarta: Penerbit Andi.

Armeini.R, Anna. (2010). Analisis Data Penelitian Kuantitatif dengan SPSS. Jakarta: Universitas Negeri Jakarta

Azwar, Saifuddin. (2010). Metode Penelitian. Yogyakarta: Pustaka Pelajar

Azwar, Saifuddin. (2010). Penyusunan Skala Psikologi. Yogyakarta: Pustaka Pelajar

Azwar, Saifuddin. (2008). Reliabilitas dan Validitas. Yogyakarta: Pustaka Pelajar.

Batbual, Bringiwatty. (2010). Hypnosis Hypnobirthing-Nyeri Persalinan dan Berbagai Metode Penanganannya. Yogyakarta: Gosyen Publishing

Chaplin, J.P. (2009). Kamus Lengkap Psikologi, (Terjemahan Kartini dan Kartono). Jakarta: Raja Grafindo Persada. 
Corey,Gerald. (2009). Teori dan Praktek Konseling dan Psikoterapi. Bandung: Rafika Aditama.

Creswell, John.W. (2010). Research Design (Pendekatan Kualitatif, Kuantitatif, dan Mixed).Yogyakarta: Pustaka Pelajar

Cunningham, Gary F. (2010). William Obstetric 23rd edition. USA: The McGraw Hill Companies, Inc.

Cyna, et.al. (2006). Hypnosis Antenatal Training for Childbirth (HATCh): a randomised controlled trial. USA: BMC Pregnancy and Childbirth.

Dacey, J. S., \& Fiore, L. B. (2005). Your Anxious Child (How Parents and Teachers Can Relieve Anxiety ini Children). San Fransisco: JosseyBass Publishers.

Dacey.John \& Travers. (2002). Human Development (Across the Lifespan). Mc Graw Hill; New York

Durand, V., \& Barlow, D. H. (2006). Psikologi Abnormal (Edisi Keempat). Yogyakarta: Pustaka Pelajar.

E.Papalia, D., Old, S. W., \& Feldman, R. D. (2008). Human Development (Psikologi Perkembangan) Edisi Kesembilan. Jakarta: Kencana Prenada Media Group.

F.Mongan, M. (2007). Hypnobirthing The Mongan Method-Metode Melahirkan Secara Aman, Mudah, dan Nyaman. Jakarta: PT Bhuana Ilmu Populer.

Fitri Fausiah. (2005). Psikologi Abnormal Klinis Dewasa. Jakarta: UI-Press

Friana, Dina. (2000). Strategi Coping Wanita Hamil Menghadapi Kecemasan Kehamilan Pertama. Skripsi (tidak diterbitkan). Depok: Universitas Indonesia.

Ganley, Jackie. (2004). Becoming a Parent (The Emotional Journey Through
Pregnancy and Chilbirth) . Inggris: John Wiley \& Sons, Ltd

Grossman, F.K, et al. (1980). Pregnancy, Birth, and Parenthood. San Fransisco: Jessey Bass Publishers

Hawari, D. (2000). Manajemen Stress, Cemas, dan Depresi. Jakarta: Fakultas Kedokteran Universitas Indonesia.

Hurlock, Elizabeth.B. (1980). Psikologi Perkembangan (Suatu Pendekatan Sepanjang Rentang Kehidupan). Jakarta: Erlangga.

Ibrahim, A. S. (2012). Panik Neurosis dan Gangguan Cemas. Tangerang: Jelajah Nusa.

Jatmika, Wahyu. (1999). Hubungan Skor Kecemasan Terhadap Lama Persalinan Kala 1. Tesis. (tidak diterbitkan). Semarang: Fakultas Kedokteran Universitas Diponegoro.

Kartono, Kartini. (1989). Psikologi Abnormal dan Abnormalitas Seksual. Mandar Maju: Bandung

Kartono, Kartini. (1992). Psikologi Wanita (Jilid 2) Mengenal Wanita Sebagai Ibu dan Nenek. Bandung: Mandar Maju.

Kuncono. (2004). Aplikasi Komputer Psikologi. Jakarta: Fakultas Psikologi Universitas Persada Indonesia.

Kusumawati, Farida \& Hartono, Yudi. (2011). Buku Ajar Keperawatan Jiwa. Jakarta: Salemba Medika

Kuswandi, Lanny. (2011). Keajaiban Hypno-Birthing (Panduan Praktis Melahirkan Alami, Lancar, dan Tanpa Rasa Sakit). Jakarta: Pustaka Bunda

Latipun. (2010). Psikologi Eksperimen (Edisi Kedua). Malang: UMM Press.

Long, Amanda Gwyne. (2009). Hypnobirth Therapy, The Answer to Pain Free 
Labour?. Archives of Family medicine 3, 10:881 : London

Malicha,Siti. (2011). Pengaruh Metode Hypnobirthing Terhadap Tingkat Kecemasan Dan Lama Proses Persalinan Pada Ibu Bersalin Di Puskesmas Blooto Kota Mojokerto. Thesis (tidak diterbitkan). Surakarta: Universitas Sebelas Maret.

Maramis, W.F. (1980). Catatan Ilmu Kedokteran Jiwa. Surabaya: Lembaga Penerbitan Universitas Airlangga.

Martin, et.al. (2001). Effects of Hypnosis on the Labour Processes and Birth Outcomes of Pregnant Adolescents. Florida:University of Florida.

Matlin.W, Margaret. (1987). The Psychology of Women; Pregnancy, Childbirth, and Motherhood. Florida: Holt,Reinhart, and Winston,Inc.

Mochtar, Rustam. (1998). Sinopsis Obstetri (Obstetri Operatif dan Obstetri Sosial). Jakarta: Penerbit Buku Kedokteran EGC.

Parlina, Nining. (2010). Pengaruh program penurunan kecemasan melalui terapi menulis buku harian terhadap siswa kelas VI sebelum menghadapi UASBN. Skripsi (tidak diterbitkan). Jakarta: Universitas Negeri Jakarta.

Peurifoy, Reneau. (2005). Anxiety, Phobias, and Panic (Revised and Updated). Warner Books: New York.

Prasertcharoensuk, Witoon \& Thinkhamrop, Jadsada. (2004). NonPharmacologic Labour Pain. Thailand: Department of Obstetrics and Gynecology, Faculty of Medicine, Khon Kaen University.

Prawirohardjo, S. (2002). Ilmu kebidanan. Jakarta : Yayasan Bina Pustaka Sarwono
Santoso,Singgih. (2006). Menggunakan SPSS untuk Statistik Non Parametrik. Jakarta: PT Elex Media Komputindo.

Santrock, John W. (2002). Life Span Development (Perkembangan Masa Hidup) 5th ed. Jakarta: Penerbit Erlangga

S.Hall, C., \& Lindzey, G. (1993). Teori-teori Psikodinamik (Klinis). Yogyakarta: Kanisius.

Seniati, L., Yulianto, A., \& Setiadi, B. N. (2011). Psikologi Eksperimen. Jakarta: PT.Ilndeks.

Siegel, Sidney. (1986). Statistik Non Parametrik untuk Ilmu-ilmu Sosial. Jakarta: Gramedia

Smith, et.al. (2006). Complementary and alternative therapies for pain management in labour (Review). John Wiley \& Sons, Ltd.

Spielberger, Charles.D. (1972). Anxiety (Current Trends ini Theory and Research) Volume II. London: Academic Press, Inc.

Stuart \& Sundden. (1998). Buku saku keperaawatan jiwa, 3rd ed. Terjemahan

oleh Achir Yani S Hamid. Jakarta: EGC.

Sugiyono. (2009). Metode Penelitian Kuantitatif, Kualitatif, dan $R \& D$. Bandung: Penerbit Alfabeta Bandung.

Sumapraja, S. (1999). Untuk suami yang istrinya hamil. Jakarta : Yayasan Sayang Ibu.

Williams, Juanita H. (1996). Psychology of Women: Behavior an a Biosocial Context. New York; W.W.Norton \& Company.inc

Wulandari, Primatia Yogi. (2006). Efektivitas Senam Hamil sebagai Pelayanan Prenatal dalam Menurunkan Kecemasan Menghadapi Persalinan Pertama. Jurnal Insan Vol.8 No.2: Fakultas Psikologi Universitas Airlangga. 
Jurnal Penelitian dan Pengukuran Psikologi

Vol. 1, No.1, Oktober 2012

Zuckerman, Marvin \& Spielberger, C.D. (1976). Emotion and Anxiety (New Concept, Methods, and Application). John Wiley and Sons: New York.

http://beritasore.com/2012/03/21/bkkbnberupaya-dongkrak-minatpasangan-usia-subur/ diakses tanggal 12 April 2012 pukul 10.08

http://www.bkkbn.go.id/berita/Pages/Kemati an-Ibu-Melahirkan-di-IndonesiaMasih-Tinggi.aspx. diakses tanggal 17 Maret 2012 jam 11.20

http://www.bkkbn.go.id/berita/Pages/BkkbnBidik-Generasi-Muda.aspx diakses tanggal 17 Maret 2012 jam 11.30 http://www.conectique.com/tips solution/pr egnancy/baby delivery/article.php? article $\mathrm{id}=6786$ diakses tanggal 21 Mei 2012 jam 19.20

http://www.mayoclinic.com/health/hypnobir thing/AN02138 diakses tanggal 20 Februari 2012 jam 21.17 